\title{
PENGARUH EKSPOR DAN IMPOR TERHADAP PRODUK DOMESTIK REGIONAL BRUTO (PDRB) PROVINSI SUMATERA UTARA TAHUN 2008-2015
}

\author{
Oleh: \\ Nofinawati, Nurul Izzah Lubis, Junaira Nasution \\ IAIN PADANGSIDIMPUAN \\ Jalan T. Rizal Nurdin Km. 4.5 Sihitang, Padangsidimpuan
}

\begin{abstract}
Abstrak
Produk Domestik Regional Bruto (PDRB) digunakan untuk mengukur Pertumbuhan ekonomi suatu daerah. Produk Domestik Regional Bruto (PDRB) Provinsi Sumatera Utara pada tahun 2008-2015 cenderung mengalami peningkatan akan tetapi ekspor dan impor mengalami fluktuatif. Peningkatan yang paling tinggi terjadi pada triwulan I 2014 dan penurunan yang paling rendah terjadi pada triwulan III 2014. Pada beberapa triwulan ekspor mengalami kenaikan namun Produk Domestik Regional Bruto (PDRB) mengalami penurunan, dan ekspor yang mengalami penurunan tidak diikuti dengan PDRB yang meningkat. Dan pada beberapa triwulan impor yang meningkat juga diikuti dengan PDRB yang meningkat, dan impor yang menurun diikuti juga dengan PDRB menurun. Penelitian ini dilakukan untuk mengetahui pengaruh ekspor dan impor terhadap PDRB Provinsi Sumatera Utara tahun 2008-2015.

Pembahasan penelitian ini berkaitan dengan pengaruh ekspor dan impor terhadap PDRB Provinsi Sumatera Utara Tahun 2008-2015. Sehubungan dengan itu, maka teori yang digunakan adalah teori Pendapatan Regional/Nasional, teori ekspor dan teori impor.

Penelitian ini dilakukan di Provinsi Sumatera Utara. Jenis penelitian yang digunakan peneliti adalah jenis penelitian kuantitatif. Penelitian ini menggunakan data time series yang diperoleh dari Badan Pusat Statistik Provinsi Sumatera Utara dan Bank Indonesia mulai tahun 2008-2015. Teknik analisis yang digunakan yaitu regresi linear berganda.

Hasil dari estimasi menunjukkan bahwa ekspor berpengaruh signifikan terhadap PDRB dengan nilai prob $0,0023<0,05$, impor berpengaruh signifikan terhadap PDRB dengan nilai prob $0,0000<0,05$. Dan secara simultan menunjukkan bahwa ekspor dan impor mempunyai pengaruh yang signifikan terhadap PDRB dengan nilai prob 0,000122 < 0,05. Nilai $\mathrm{R}^{2}$ sebesar 0.462972, yang berarti bahwa ekspor dan impor mampu menjelaskan variasi PDRB sebesar 46,29 persen. Sedangkan, sisanya sebesar 53,71 persen dipengaruhi variabel lain yang tidak digunakan dalam penelitian ini.
\end{abstract}

Kata Kunci : Ekspor, Impor, Produk Domestik Regional Bruto (PDRB)

\section{PENDAHULUAN}

Negara-negara di dunia pada saat ini dapat dikatakan tidak ada yang mampu memisahkan dirinya dengan negara lain terutama dalam memenuhi kebutuhannya. Suatu negara dapat saja memenuhi salah satu kebutuhannya, namun dilain pihak ada kebutuhan lain yang 
tidak dapat dipenuhi dari dalam negeri karena alasan-alasan tertentu seperti keterbatasan dalam sumber daya alam, kekurangan modal, skill yang belum memadai dan lain-lain. Kebutuhan demikian ini biasanya diperoleh dari negara lain melalui kegiatan perdagangan. Jadi telah terbentuk saling ketergantungan antara negara-negara yang ada di dunia ini.

Perdagangan internasional juga disebut-sebut sebagai suatu mekanisme untuk mewujudkan ketidakseragaman internasional (mechanism of international inequality). Melalui interaksi berbagai kekuatan di pasar menyebabkan setiap negara berbeda dengan negara-negara lainnya baik dalam hal tingkat pembangunan ekonomi maupun pendapatan perkapita.

Pendapatan perkapita adalah total pendapatan suatu daerah dibagi jumlah penduduk di daerah tersebut untuk tahun yang sama. Angka yang digunakan semestinya adalah total pendapatan regional dibagi jumlah pendapatan regional dibagi jumlah penduduk. Akan tetapi, angka ini seringkali tidak diperoleh sehingga diganti dengan total Produk Domestik Regional Bruto (PDRB) atas dasar harga pasar dibagi dengan jumlah penduduk. ${ }^{1}$

Produk Domestik Bruto (PDB) pada tingkat nasional serta Produk Domestik Regional Bruto (PDRB) pada tingkat regional (provinsi) menggambarkan kemampuan suatu wilayah untuk menciptakan nilai tambah pada suatu waktu tertentu. Untuk menyusun PDB maupun PDRB digunakan dua pendekatan, yaitu lapangan usaha dan pengeluaran. Keduanya menyajikan komposisi data nilai tambah dirinci menurut sumber kegiatan ekonomi (lapangan usaha) dan menurut komponen penggunaannya. ${ }^{2}$

Ekspor neto adalah total ekspor dikurangi total impor. Total penyediaan (total barang dan jasa yang tersedia) di dalam negeri adalah total yang diproduksi ditambah impor dikurangi ekspor. Karena yang akan dihitung hanya nilai barang dan jasa yang berasal dari produksi dalam negeri saja maka total konsumsi harus dikurangi dengan nilai impor kemudian ditambah dengan nilai ekspor. ${ }^{3}$

Ekspor dan impor memegang peran penting dalam kegiatan perekonomian suatu negara. Ekspor akan menghasilkan devisa yang akan digunakan untuk membiayai impor bahan baku dan barang modal yang diperlukan dalam proses produksi yang akan membentuk nilai tambah. Agregasi nilai tambah yang dihasilkan oleh seluruh unit produksi dalam perekonomian merupakan nilai Produk Domestik Bruto. 4

\footnotetext{
${ }^{1}$ Robinson Tarigan, Ekonomi Regional Teori dan Aplikasi (Jakarta: Bumi Aksara, 2005), hlm. 18-19.

${ }^{2}$ Prathama Rahardja dan Mandala Manurung, Pengantar Ilmu Ekonomi (Mikroekonomi \& Makroekonomi) edisi ketiga (Bandung: Fakultas Ekonomi Universitas Indonesia, 2008), hlm. 233.

${ }^{3}$ Robinson Tarigan, Op. Cit., hlm. 25.

${ }^{4}$ Mustika,dkk, "Pengaruh Ekspor dan Impor Minyak Bumi Terhadap Pertumbuhan Ekonomi Indonesia", dalam jurnal Perspektif Pembiayaan dan Pembangunan Daerah, Volume 2, No.3, Januari-Maret 2015. hlm. 108.
} 
Provinsi Sumatera Utara merupakan provinsi yang meningkatkan pendapatan regionalnya dengan baik. Salah satunya melalui perdagangan internasional. Hasil sementara penghitungan Produk Domestik Regional Bruto (PDRB) menunjukkan dari 33 provinsi di Indonesia, Provinsi Sumatera Utara merupakan peringkat keenam dengan nilai Produk Domestik Regional Bruto (PDRB) sebesar Rp. 571.720.000.000.000.5

Provinsi Sumatera Utara juga merupakan provinsi yang giat melakukan ekspor. Komoditi utama ekspor Sumatera Utara adalah minyak/lemak nabati dan hewani. 6 Sumatera Utara umumnya mengekspor komoditinya ke Amerika Serikat yang mencapai US\$. 886.ooo.ooo dan Tiongkok yang mencapai US\$. 846.000.000.7

Sektor eksternal menjadi salah satu motor penting dalam mendorong pertumbuhan perekonomian Sumatera Utara pada triwulan IV 2016. Perbaikan harga komoditas yang secara signifikan terjadi pada triwulan IV mendorong melonjaknya kinerja ekspor luar negeri Sumatera Utara, terutama untuk komoditas kelapa sawit. Nilai penjualan ekspor luar negeri meningkat signifikan dengan volume ekspor sedikit lebih rendah dibandingkan triwulan IV 2015. Pada triwulan IV 2016, ekspor luar negeri Sumatera Utara tercatat membaik dari -10,6 persen menjadi -0,7 persen. Mulai menggeliatnya industri manufaktur negara tujuan ekspor utama turut berkontribusi pada perbaikan kinerja perdagangan Sumut di pasar internasional.

Tingginya dominasi produk ekstraktif dalam komoditas ekspor menyebabkan tingginya pengaruh pasar komoditas terhadap kinerja ekspor Sumatera Utara. Kinerja ekspor Sumatera Utara masih bergantung pada kinerja perekonomian beberapa mitra dagang utama seperti Amerika Serikat, Tiongkok, India dan Euro Area. Ekspor ke empat negara tersebut mencapai sekitar 43,1 persen, meningkat dibanding triwulan sebelumnya yang sebesar 39,2 persen terhadap total ekspor Sumatera Utara. ${ }^{8}$

Masih kuatnya ekonomi domestik serta kinerja ekspor yang mulai pulih mendorong perbaikan kinerja impor dari -2,6 persen menjadi 1,5 persen. Perbaikan kinerja impor didorong oleh perbaikan kinerja impor luar negeri maupun antara daerah. Peningkatan impor antar daerah terjadi seiring dengan tingginya konsumsi masyarakat dalam menyemarakkan perayaan natal dan persiapan tahun baru. Dengan demikian, kinerja impor antar daerah meningkat dari -1,9 persen menjadi 0,8 persen. 9

${ }^{5}$ Badan Pusat Statistik, Sumatera Utara Dalam Angka 2016 di akses 21 Februari 2017 pukul 09.48 WIB.

${ }^{6}$ Ibid.

${ }^{7}$ Ibid.

${ }^{8}$ Bank Indonesia, Kajian Ekonomi dan Keuangan Regional Provinsi Sumatera Utara November 2016 (Medan: Bank Indonesia, 2016), hlm. 10.

${ }^{9}$ Ibid., hlm. 12. 
Senada dengan impor antar daerah, impor luar negeri juga menunjukkan peningkatan yaitu dari 10,8 persen menjadi 17,3 persen. Peningkatan impor luar negeri terutama untuk kelompok barang-barang modal, sementara impor bahan baku dan barang konsumsi relatif menurun. Tren penguatan nilai tukar yang terus berlanjut mendorong harga barang impor yang lebih murah sehingga mampu menunjang kinerja impor.

Secara keseluruhan tahun, kinerja impor Sumatera Utara relatif membaik dari -4,1 persen menjadi -1,9 persen. Meningkatnya kinerja impor terutama didorong oleh peningkatan impor luar negeri sementara impor antar daerah justru terkontraksi. Meningkatnya impor luar negeri terkait dengan penguatan nilai tukar yang terjadi sepanjang tahun 2016 sehingga mendorong harga barang impor yang lebih terjangkau. ${ }^{10}$

Pada triwulan I-II 2008 ekspor menurun dan telah mencapai 1,9 persen dan PDRB menurun dan telah mencapai 3,96. Pada triwulan IV 2008 ekspor menurun sebesar 3,7 persen, sedangkan PDRB meningkat sebesar 4,8 persen, triwulan II 2009 ekspor kembali meningkat sebesar 2,5 persen dan PDRB menurun sebesar 3,6 persen. Triwulan I 2010 ekspor menurun sebesar 2,1 persen dan PDRB meningkat sebesar 5,3 persen, triwulan II 2010 ekspor meningkat sebesar 2,1 persen dan PDRB menurun sebesar 3,4 persen. Tahun 2011 sampai tahun 2014 ekspor dan PDRB mengalami fluktuasi. Dan pada triwulan I 2015 ekspor menurun sebesar 1,9 persen dan PDRB meningkat sebesar 4,3 persen, triwulan II 2015 ekspor kembali meningkat sebesar 4,7 persen sedangkan PDRB menurun sebesar 5,1 persen.

Pada triwulan III 2008 impor meningkat sebesar 1,7 persen dan PDRB juga meningkat sebesar 3,3 persen, triwulan III-IV 2009 impor tetap meningkat sebesar -11,8 persen, begitu juga dengan PDRB yaitu sebesar 5,7 persen. Pada tahun 2010-2013 impor dan PDRB mengalami fluktuasi. Pada triwulan III 2014 impor menurun sebesar -7,3 persen dan PDRB juga mengalami penurunan sebesar 2,5 persen. Pada triwulan IV 2015 impor telah mencapai -4,1 persen dan PDRB sebesar 97,5 persen. Mengingat impor adalah suatu bocoran dari pendapatan suatu wilayah maka dapat kita simpulkan bahwa disaat impor mengalami kenaikan maka akan berpengaruh negatif terhadap Produk Domestik Regional Bruto (PDRB), dan begitu pula sebaliknya. Fenomena inilah yang menyebabkan peneliti tertarik untuk mengangkat permasalahan ini menjadi sebuah penelitian, dengan judul "Pengaruh Ekspor dan Impor Terhadap Produk Domestik Regional Bruto (PDRB) Provinsi Sumatera Utara Tahun 2008-2015".

\footnotetext{
${ }^{10}$ Ibid., hlm. 13 .
} 


\section{LANDASAN TEORI}

\section{Produk Domestik Regional Bruto (PDRB)}

Produk Domestik Regional Bruto (PDRB) atas dasar harga pasar adalah jumlah nilai tambah bruto yang timbul dari seluruh sektor perekonomian di wilayah itu. Yang dimaksud dengan nilai tambah bruto adalah nilai produksi dikurangi dengan biaya antara. ${ }^{11}$

\section{Metode Perhitungan Pendapatan Regional}

Ada dua metode yang dapat dipakai untuk menghitung pendapatan regional, yaitu metode langsung dan tidak langsung. ${ }^{12}$

Metode langsung adalah perhitungan dengan menggunakan data daerah atau data asli yang menggambarkan kondisi daerah dan digali dari sumber data yang ada di daerah itu sendiri. Pemakaian metode ini dapat dilakukan melalui tiga pendekatan, yaitu metode produksi, metode pendapatan dan metode pengeluaran. Masing-masing metode (pendekatan) melihat pendapatan nasional dari sudut pandang yang berbeda, tetapi hasilnya saling melengkapi. ${ }^{13}$

\section{Pendekatan produksi}

Menurut metode ini, PDB adalah total output (produksi) yang dihasilkan oleh suatu perekonomian. Cara penghitungan dalam praktik adalah dengan membagi-bagi perekonomian menjadi beberapa sektor produksi (industrial origin). Jumlah output masingmasing sektor merupakan jumlah output seluruh perekonomian. Hanya saja, ada kemungkinan bahwa output yang dihasilkan suatu sektor perekonomian berasal dari output sektor lain atau bisa juga merupakan input bagi sektor ekonomi yang lain lagi. Dengan kata lain, jika tidak berhati-hati akan terjadi penghitungan ganda (double counting) atau bahkan multiple counting. Akibatnya angka PDB bisa menggelembung beberapa kali lipat dari angka yang sebenarnya.

Model untuk pendekatan produksi dapat ditulis melalui persamaan berikut: ${ }^{14}$

$$
\mathrm{PDB}=\sum_{\mathrm{i}-1}^{\mathrm{n}} \mathrm{NT}
$$

\section{Keterangan:}

$\mathrm{i} \quad=$ sektor produksi ke $1,2,3, \ldots ., \mathrm{n}$

\footnotetext{
${ }^{11}$ Robinson Tarigan, Op. Cit., hlm. 18.

12 Ibid., hlm. 23.

${ }^{13}$ Prathama Rahardja dan Mandala Manurung, Op. Cit., hlm. 229.

14 Ibid.
} 


\section{Pendekatan pendapatan}

Perhitungan pendapatan nasional dengan menggunakan pendekatan ini adalah dengan menjumlahkan semua pendapatan yang diperoleh semua pelaku ekonomi dalam suatu masyarakat atau negara pada periode tertentu. Pendapatan tersebut berupa pendapatan dari sewa, bunga, upah, keuntungan dan lain sebagainya. Angka yang diperoleh dari perhitungan pendapatan nasional dengan menggunakan metode ini menunjukkan besarnya pendapatan nasional (national income $=\mathrm{NI}$ ). Model untuk pendekatan pendapatan dapat ditulis melalui persamaan berikut: ${ }^{15}$

$$
\mathrm{Y}=\mathrm{R}+\mathrm{W}+\mathrm{I}+\mathrm{P}
$$

$$
\begin{aligned}
& \text { Keterangan: } \\
& \mathrm{Y}=\text { Pendapatan nasional } \\
& \mathrm{R}=\text { Sewa } \\
& \mathrm{W} \quad=\text { Upah dan gaji } \\
& \text { I }=\text { Bunga } \\
& \mathrm{P}=\text { Laba/ Profit }
\end{aligned}
$$

\section{Pendekatan pengeluaran}

Pendekatan ini dilakukan dengan menjumlah seluruh pengeluaran seluruh sektor ekonomi. Angka yang diperoleh dari perhitungan pendapatan nasional dengan metode ini menunjukkan besarnya produksi nasional bruto (Gross National Product = GNP) masyarakat dalam pereknomian tersebut. ${ }^{16}$

Pengeluaran konsumsi, investasi, pengeluaran pemerintah dan ekspor adalah faktor yang memberikan pengaruh positif terhadap pendapatan nasional. Sedangkan impor memberikan pengaruh yang sebaliknya. Ekspor merupakan masukan atau suntikan terhadap pendapatan nasional. Pendapatan nasional akan mengalami pertumbuhan jika ekspor meningkat, dan akan menurun jika ekspor mengalami penurunan. Dan impor merupakan pengeluaran atau bocoran dari pendapatan nasional. Pendapatan nasional akan mengalami penurunan jika impor meningkat, dan akan meningkat jika impor mengalami penurunan. Model untuk pendekatan pendapatan dapat ditulis melalui persamaan berikut: ${ }^{17}$

\footnotetext{
${ }^{15}$ Ibid., hlm. 232.

${ }^{16}$ Masyhuri Machfudz dan M. Nurhadi Sujoni, Op. Cit., hlm. 25-26.

${ }^{17}$ Ibid.
} 


$$
\mathrm{Y}=\mathrm{C}+\mathrm{I}+\mathrm{G}+(\mathrm{X}-\mathrm{M})
$$

\section{Keterangan:}

$\begin{array}{ll}\mathrm{Y} & =\text { Pendapatan } \\ \mathrm{C} & =\text { Pengeluaran Konsumsi } \\ \mathrm{I} & =\text { Investasi } \\ \mathrm{G} & =\text { Pengeluaran Pemerintah } \\ \mathrm{X} & =\text { Ekspor } \\ \mathrm{M} & =\text { Impor }\end{array}$

Metode tidak langsung yaitu menghitung nilai tambah suatu kelompok ekonomi dengan mengalokasikan nilai tambah nasional ke dalam masing-masing kelompok kegiatan ekonomi pada tingkat regional. Sebagai alokator digunakan indikator yang paling besar pengaruhnya atau erat kaitannya dengan produktivitas kegiatan ekonomi tersebut. ${ }^{18}$

Pemakaian masing-masing metode pendekatan sangat tergantung pada data yang tersedia. Pada kenyataannya, pemakaian kedua metode tersebut akan saling menunjang satu sama lain, karena metode langsung akan mendorong peningkatan kualitas data daerah, sedang metode tidak langsung akan merupakan koreksi dalam pembanding bagi data daerah. ${ }^{19}$

\section{METODOLOGI PENELITIAN}

Penelitian ini dilakukan di website resmi Badan Pusat Statistik Sumatera Utara dalam Angka yang di publikasikan oleh Provinsi Sumatera Utara. Penelitian ini dimulai pada bulan Mei 2017 sampai bulan September 2017.

Jenis penelitian yang digunakan peneliti di sini adalah jenis penelitian kuantitatif. Kuantitatif adalah penelitian yang menggunakan rumus-rumus tertentu yang disesuaikan dengan topik permasalahan yang akan diteliti. ${ }^{20}$ Penelitian kuantitatif adalah penelitian yang menggunakan pengukuran dengan angka dan dianalisis dengan menggunakan statistik. ${ }^{21}$ Penelitian ini menggunakan data time series dari tahun 2008-2015. Yang menjadi variabel bebas (X) dalam penelitian ini adalah ekspor (X1) dan impor (X2) sedangkan variabel terikatnya (Y) adalah PDRB (Produk Domestik Regional Bruto).

\footnotetext{
${ }^{18}$ Robinson Tarigan, Op. Cit., hlm. 25.

${ }^{19}$ Ibid.

${ }^{20}$ Iskandar, Metodologi Pendidikan dan Sosial (Jakarta: Gaung Persada Press, 2008), hlm. 17.

${ }^{21}$ Panduan Penulisan Skripsi (Padangsidimpuan: STAIN Padangsidimpuan, 2012), hlm. 45.
} 


\section{HASIL PENELITIAN}

\section{Pengaruh Ekspor Terhadap Produk Domestik Regional Bruto (PDRB)}

Hasil regresi ekspor menunjukkan bahwa nilai yang diperoleh dari koefisien sebesar 8292.922. Hal ini berarti ekspor memiliki pengaruh yang negatif terhadap Produk Domestik Regional Bruto (PDRB). Dimana apabila ekspor mengalami kenaikan Rp. 1.ooo.ooo juta maka Produk Domestik Regional Bruto (PDRB) akan turun sebesar Rp. -8292.922 juta dengan asumsi impor tetap. Adapun dengan menggunakan uji t pada tingkat signifikansi 5 persen, ekspor memiliki nilai prob. t-statistik sebesar 0.0023 lebih kecil dari o,05. Hal ini berarti ekspor yang menurun berpengaruh signifikan terhadap Produk Domestik Regional Bruto (PDRB) Provinsi Sumatera Utara.

Hasil penelitian ini sejalan dengan penelitian Mustika, Haryadi dan Siti Hodijah yang berjudul "Pengaruh Ekspor Dan Impor Minyak Bumi Terhadap Pertumbuhan Ekonomi Indonesia”. Dalam penelitian tersebut ekspor berpengaruh negatif dan signifikan terhadap pertumbuhan ekonomi Indonesia dalam jangka panjang. Artinya, ketika ekspor menurun maka pertumbuhan ekonomi di Indonesia akan meningkat.

Hasil penelitian ini bertolak belakang dengan teori yang dikemukakan oleh Sadono Sukirno, dalam buku yang berjudul "Makro Ekonomi Teori Pengantar" ekspor akan secara langsung mempengaruhi pendapatan nasional. Akan tetapi, hubungan yang sebaliknya tidak selalu berlaku, yaitu kenaikan pendapatan nasional belum tentu menaikkan ekspor oleh karena pendapatan nasional dapat mengalami kenaikan sebagai akibat dari kenaikan pengeluaran rumah tangga, investasi perusahaan, pengeluaran pemerintah dan penggantian barang impor dengan barang buatan dalam negeri.

Ekspor memiliki pengaruh negatif dan signifikan terhadap Produk Domestik Regional Bruto (PDRB) Provinsi Sumatera Utara. Artinya, tingkat ekspor rendah akan meningkatkan Produk Domestik Regional Bruto (PDRB). Pemerintah harus mampu menjaga kestabilan surplus perdagangan untuk meningkatkan neraca perdagangan dan membuat kebijakan-kebijakan dalam meningkatkan produksi barang-barang unggulan ekspor Provinsi Sumatera Utara.

\section{Pengaruh Impor Terhadap Produk Domestik Regional Bruto (PDRB)}

Hasil regresi menunjukkan bahwa nilai yang diperoleh dari koefisien impor sebesar 23943.92. Hal ini berarti impor memiliki pengaruh positif terhadap Produk Domestik Regional Bruto (PDRB). Dimana ketika impor mengalami kenaikan Rp. 1.00o.ooo juta maka Produk Domestik Regional Bruto (PDRB) akan mengalami kenaikan sebesar Rp. 23943.92 juta dengan asumsi ekspor tetap. Dengan menggunakan uji t pada tingkat signifikansi 5 persen, variabel impor memiliki nilai prob. t-statistik sebesar 0.0000 yang lebih kecil dari 0,05. Hal ini berarti impor 
berpengaruh positif dan signifikan terhadap Produk Domestik Regional Bruto (PDRB) Provinsi Sumatera Utara.

Hasil penelitian ini sejalan dengan penelitian Mustika, Haryadi dan Siti Hodijah yang berjudul "Pengaruh Ekspor Dan Impor Minyak Bumi Terhadap Pertumbuhan Ekonomi Indonesia”. Dalam penelitian tersebut impor berpengaruh positif dan signifikan terhadap pertumbuhan ekonomi Indonesia dalam jangka panjang. Artinya, ketika impor meningkat maka pertumbuhan ekonomi di Indonesia akan meningkat.

Hasil penelitian ini bertolak belakang dengan teori yang dikemukakan oleh Sadono Sukirno, dalam buku yang berjudul "Makro Ekonomi Teori Pengantar" Secara fisik, impor merupakan pembelian dan pemasukan barang dari luar negeri ke dalam suatu perekonomian. Aliran barang ini akan menimbulkan aliran keluar atau bocoran dari aliran pengeluaran dari sektor rumah tangga ke sektor perusahaan. Aliran keluar atau bocoran ini pada akhirnya akan menurunkan pendapatan nasional yang dapat dicapai.

Impor memiliki pengaruh positif dan signifikan terhadap Produk Domestik Regional Bruto (PDRB) Provinsi Sumatera Utara. Artinya, impor tinggi akan meningkatkan Produk Domestik Regional Bruto (PDRB) Provinsi Sumatera Utara. Pemerintah harus lebih teliti dalam melihat persediaan yang ada dan membuat kebijakan-kebijakan dalam memproduksi barang-barang yang langka sekaligus barangbarang pengganti. Supaya transaksi impor tidak melebihi nilai ekspor dan tidak mengurangi pendapatan.

\section{Pengaruh Ekspor dan Impor Terhadap Produk Domestik Regional Bruto (PDRB) Provinsi Sumatera Utara}

Hasil regresi menunjukkan bahwa nilai konstanta yang diperoleh sebesar 2.70E+13. Dimana ketika ekspor dan impor diasumsikan o, maka Produk Domestik Regional Bruto (PDRB) sebesar Rp. 2.70E+13 juta. Dengan menggunakan uji F pada tingkat signifikansi 5 persen, diperoleh nilai prob. F-statistik sebesar $0.000122<0,05$. Artinya, ekspor dan impor mempunyai pengaruh yang signifikan terhadap Produk Domestik Regional Bruto (PDRB) Provinsi Sumatera Utara. hasil uji koefisien determinasi $\left(\mathrm{R}^{2}\right)$ sebesar 0.462972 . Hal ini berarti bahwa variabel ekspor dan impor mampu menjelaskan variasi Produk Domestik Regional Bruto (PDRB) sebesar 46,29 
persen sedangkan sisanya sebesar 53,71 persen dipengaruhi oleh variabel lain yang tidak dimasukkan dalam model penelitian ini.

Hasil penelitian ini sejalan dengan teori yang dikemukakan oleh Prathama Rahardja dan Mandala Manurung dalam bukunya "Pengantar Ilmu Ekonomi (Mikroekonomi \& Makroekonomi) Edisi Ketiga" sektor rumah tangga, perusahaan, dan pemerintah merupakan perekonomian domestik. Perekonomian dikatakan tertutup (closed economy), jika tidak melakukan interaksi dengan sektor luar negeri. Interaksi dengan sektor luar negeri dalam perekonomian terbuka (open economi) disederhanakan dengan mekanisme ekspor dan impor. Ekspor merupakan aliran pendapatan dari sektor luar negeri ke perekonomian domestik. Sedangkan impor merupakan aliran pengeluaran dari perekonomian domestik ke sektor luar negeri.

Hasil penelitian ini sejalan dengan penelitian Siti Mahmudah yang berjudul "Pengaruh Nilai Tambah Industri, Ekspor, Impor dan Investasi Dalam Negeri (PMDN) Terhadap Pertumbuhan Ekonomi Kota Jakarta Produk Domestik Regional Bruto (PDRB)". Dalam hasil penelitian tersebut nilai tambah industri, impor, investasi (PMDN) dan ekspor berpengaruh signifikan terhadap pertumbuhan ekonomi Kota Jakarta Produk Domestik Regional Bruto (PDRB).

Hasil penelitian ini sejalan dengan penelitian Ayunia Pridayanti yang berjudul "Pengaruh Ekspor, Impor, dan Nilai Tukar Terhadap Pertumbuhan Ekonomi Di Indonesia”. Dalam hasil penelitian tersebut variabel ekspor, impor dan nilai tukar berpengaruh signifikan terhadap pertumbuhan ekonomi.

Hasil penelitian ini sejalan dengan penelitian Mustika, Haryadi dan Siti Hodijah yang berjudul "Pengaruh Ekspor Dan Impor Minyak Bumi Terhadap Pertumbuhan Ekonomi Indonesia”. Dalam hasil penelitian tersebut nilai ekspor dan impor minyak bumi berpengaruh signifikan terhadap pertumbuhan ekonomi.

\section{DAFTAR PUSTAKA}

Badan Pusat Statistik Provinsi Sumatera Utara, Sumatera Utara dalam Angka

Bank Indonesia, Kajian Ekonomi dan Keuangan Regional Provinsi Sumatera Utara November 2016, Medan: Bank Indonesia, 2014.

Bank Indonesia, Kajian Ekonomi dan Keuangan Regional Provinsi Sumatera Utara November 2016, Medan: Bank Indonesia, 2015. 
Bank Indonesia, Kajian Ekonomi dan Keuangan Regional Provinsi Sumatera Utara November 2016, Medan: Bank Indonesia, 2016.

Burhan Bungin, Metodologi Penelitian Kuantitatif, Jakarta: Prenada Media, 2005.

Departemen Agama, Al-qur'an dan Terjemahnya Al-Jumanatul 'Ali, Bandung: CV J-Art, 2004.

Dwi Priyatno, Mandiri Belajar SPSS, Yogyakarta: Mediakom, 2008.

Hendri Tanjung dan Abrista Dewi, Metode Penelitian Ekonomi Islam, Jakarta: Gramata Publishing, 2013.

Hutabarat. R, Transaksi Ekspor Impor, Jakarta: Erlangga, 1996.

Iskandar, Metodologi Pendidikan dan Sosial, Jakarta: Gaung Persada Press, 2008.

Imam Ghozali, Aplikasi Analisis Multivariate Dengan Program SPSS, Semarang: 2005.

Junaiddin Zakaria, Pengantar Teri Ekonomi Makro, Jakarta: Gaung Persada Press, 2009.

Masyhuri Machfudz dan M. Nurhadi Sujoni, Teori Ekonomi Makro, Malang: UIN-Maliki Press, 2012.

Mudrajad Kuncoro, Metode Riset untuk Bisnis dan Ekonomi, Jakarta: Erlangga, 2009.

Muhammad, Metodologi Penelitian Ekonomi Islam Pendekatan Kuantitatif, Jakarta: Rajawali Pers, 2008.

Muhammad Sharif Chaudhry, Sistem Ekonomi Islam Prinsip Dasar, Jakarta: Kencana, 2012.

Mustika.dkk, "Pengaruh Ekspor dan Impor Minyak Bumi terhadap Pertumbuhan Ekonomi Indonesia”,dalam jurnal Perspektif Pembiayaan dan Pembangunan Daerah, Volume 2, No.3, Januari-Maret 2015.

Nasution, Mustafa Edwin.dkk, Pengenalan Eksklusif Ekonomi Islam, Jakarta: Kencana Prenada Media Group, 2006.

N.Gregory Mankiw, Pengantar Ekonomi, Jakarta: Erlangga, 2000.

Panduan Penulisan Skripsi, Padangsidimpuan: STAIN Padangsidimpuan, 2012.

Prathama Rahardja dan Mandala Manurung, Pengantar Ilmu Ekonomi (Mikroekonomi \& Makroeknomi), Bandung: Fakultas Ekonomi Universitas Indonesia, 2008.

Punaji Setyosari, Metode Penelitian Pendidikan, Jakarta: Kencana Prenada Media Grup, 2012.

Robinson Tarigan, Ekonomi Regional Teori dan Aplikasi, Jakarta: Bumi Aksara, 2005.

Rozalinda, Ekonomi Islam Teori Dan Aplikasinya Pada Aktivitas Ekonomi, Jakarta: PT. Raja Grafindo Persada, 2014. 
Sadono Sukirno, Makroekonomi Teori Pengantar, Jakarta: PT Raja Grafindo Persada, 2004. , Makro Ekonomi Teori Pengantar, Jakarta: PT. Raja Grafindo Persada, 2008.

Saifuddin Azwar, Metode Penelitian, Yogyakarta: Pustaka Pelajar, 2004.

Shochrul Ajija, dkk, Cara Cerdas Menguasai EViews, Jakarta: Salemba Empat, 2011.

Siregar Syofyan, Metode Penelitian Kuantitatif: Dilengkapi Dengan Perbandingan Perhitungan Manual \& SPSS, Cetakan ke-1, Jakarta: Kencana Prenada Media Group.

Sugiyono, Metode Penelitian Bisnis, Bandung: Alfabeta, 2012. , Metode Penelitian Kwantitatif, Kwalitatif dan R \& D, Jakarta: Alfabeta, 2013.

Suharsimi Arikunto, Produser Penelitian: Suatu Pendekatan Praktek, Edisi Revisi VI, Jakarta: Rineka Cipta, 2006.

Sukardi, Metodologi Penelitian Pendidikan, Jakarta: PT Bumi Aksara, 2003.

Tambunan Tulus, Perdagangan Internasional dan Neraca Pembayaran Teori dan Temuan Empiris, Jakarta: pustaka LP3ES, 2000.

Todaro.P, Pembangunan Ekonomi Dunia ke Tiga, Edisi 7, Jakarta: Erlangga, 2002. 